\title{
Plants as Antiviral Agents
}

\section{Hoda MA Waziri*}

Plant Virus and Phytoplasma Research Department, Plant Pathology Research Institute, Agricultural Research Center, Cairo, Egypt

\begin{abstract}
Viruses are microorganisms that infect all kinds of living organisms including plants, and cause remarkable lose in crop production. Although pesticides showed that they can protect plants from pest infections, there are no effective substances that can be used as potent virucides. Therefore, there is a continuous demand to produce chemicals in order to stop and cure viral infections in plants. However, toxicity and carcinogenicity issues were always attributed to chemical pesticides. Screening of natural products shined in the dark to find new safe virucides. The philosophy of selecting those plants is oriented towards plants that can protect themselves from viral infections. Plants have been reported as virus inhibitors and are able to prevent infection of viruses by inducing systemic resistance in noninfested parts of the plants, such as Boerhaavia diffusa, Clerodendrum aculeatum. Other plants defend themselves against virus infections; these plants contain ribosome inactivating proteins [RIPs], such as Phytolacca Americana, Mirabilis jalapa, Dianthus caryophullus. The methods used for extraction, separation, identification of those antiviral compounds are documented and discussed in this review.
\end{abstract}

Keywords: Plant virus; Antiviral activities; Antiviral evaluation; Systemic resistance inducers; Ribosome-inactivating proteins

\section{Introduction}

Viruses are microorganisms which are able to infect all kinds of living organisms and the most important hosts are humans, animals, plants, bacteria and fungi. However few viruses are able to infect more than one organism [1]. An enormous numbers of plant viruses have been identified, and almost reached one thousand [2]. Plant viruses are extended through higher plants which are considered to be natural hosts [3]. Mostly all kinds of cultivated and non-cultivated plants could be infected with viruses, but each virus has a different host range [4]. Tobacco Mosaic Virus [TMV] for example is capable of infecting over 1000 species in 85 different plant families [4], on the other hand, some viruses are unable to infect but only few species in the grass family [3], for instance, Citrus Tristeza Virus [CTV] is able to infect few species in Citrus genus [4]. Virus infection can be transmitted from an infected plant to any healthy plants all over the field, and it is impossible to cure or to make a plant free virus once it has been became infected. Therefore, perennial crop virus infection could be problematic. In fact, the infected plants must be eliminated and a new one replanted which will take a long time before we can get any economic return [3]. Crop losses due to virus diseases all over the world are estimated by 60 billion US dollars per year [3]. Losses in tomato could reach up to $100 \%$ by Tomato Yellow Leaf Curl Virus [TYLCV] in many countries around the world [5], also the loss caused by TMV and Cucumber Mosaic Virus [CMV], reached a billion dollar [3]. Africa suffers from losses which are evaluated by around 50,000 tons of cocoa beans each year caused by Cacao swollen shoot virus. Rice tungro virus in the Southeast Asia causes losses with an estimate of $\$ 1.5$ billion dollars annually, the economic losses estimated by 1 billion dollar for Tomato spotted wilt virus which is able to infect different crops beside tomato, peanut and tobacco [1].

\section{Materials and Methods}

\section{Classical chemicals used as virucides}

Different strategies were used to control viral diseases which couldn't have been effective in decreasing or avoiding the virus infection, despite controlling fungi or bacteria were very effective; especially by chemical means [2]. In fungal diseases using fungicides is a very important way to protect crops from infections and to decrease fungal diseases. However, for virus diseases there is no such direct way available to control it so far [6]. Researches for virucide seem to be far behind when compared to similar areas using chemical compounds such as herbicide, fungicide and insecticide. Antiviral substances are strongly in demand to control virus diseases, but it has been documented that the agriculture field lacks antiviral chemicals [3]. Several chemicals have been found to be able to control virus replication and suppress virus disease symptoms [7], such as "benlate" and "bavistin", but unfortunately these chemicals failed to have any effect on the quantity of the virus in the leaves. Another problem is that many of these chemicals have negative properties such as, phytotoxic effects, probably bad effect on humans, animals, and the environment, so none of these compounds are used in applied fields for controlling plant viruses. These disadvantages make the regulations for the registration of any new chemical virucides very restricted and increases firmness of the regulations in many countries. The near future probably will not see any considerable progress of chemical virucides [8].

A combination of heat treatment or meristem tip culture and chemical treatments in a few cases may have been useful [6]. In apple shoot cultures ribavirin [virazole], an analog of guanosine has been used to eliminate Apple Chlorotic Leaf Spot Virus [ACLSV] in combination with tissue culture $[9,10]$, used it in Cymbidium cultures to eradicate Odontoglossum Ringspot Virus [ORSV]. Potato viruses have been eliminated in potato meristem culture by using 2,4-dioxohexahydro1,3,5-triazine [11], and potato stem cuttings [12]. Several compounds have been tested as antiviral against viruses infecting plants. These chemicals were produced from plants, other organisms and also synthetic organic chemicals, all of them nearly if applied to the

*Corresponding author: Hoda Waziri MA, Plant Virus \& Phytoplasma Research Department, Plant Pathology Research Institute, Agricultural Research Center, Cairo, Egypt, Tel: 5721207-5723301; E-mail: h_waziri@yahoo.com

Received November 29, 2014; Accepted February 08, 2015; Published February 26, 2015

Citation: Waziri HMA (2015) Plants as Antiviral Agents. J Plant Pathol Microb 6 : 254. doi:10.4172/2157-7471.1000254

Copyright: (c) 2015 Waziri HMA. This is an open-access article distributed under the terms of the Creative Commons Attribution License, which permits unrestricted use, distribution, and reproduction in any medium, provided the original author and source are credited. 
leaves before inoculation, or shortly after inoculation affect virus infectivity. For instance, a component produced from Phytophthora megaspermafs. P. glycinea called "glucan" has an inhibiting effect on a number of viruses but the mode of action remains unknown [13]. Several scientists reviewed work in this field as [14-16]. Many synthetic analogs for these bases including nucleic acids [purine and pyrimidine] have been studied very well and the research continues for compounds of this type [17]. Virazole was found to have a wide-spectrum effect on the virus system of experimental animals [18].

The antiviral activity of Virazole has been studied in different plant virus systems. It suppresses and slows down the systemic infection with Tomato Spotted Wilt Virus [TSWV] and also tobacco plants if pretreated with it. It also decreases the concentration of CMV and Alfalfa Mosaic Virus [AMV] in tissue culture plant. However, in meristem tip cultures, virus free plants were obtained with or without virazol being added to the medium. Murphy et al. reported that Plant Growth Promoting Rhizoctinia [PGPR] reduced the severity of the infection of Tomato Mottle Virus [ToMoV] which infects the tomato plants. Hence, PGPR was suggested to be used in the management of ToMoV on tomato plants within the integrated program. Also, it was observed that, when a high dose of nitrogen fertilizers were used, suppression of virus disease symptoms occurred but without an effect on the virus concentration [19]. Significant efforts have been made to find components that can be used as inhibitors of virus infection and replication that works as fungicides and give direct protection to the crops against fungi, but such substances are not available yet [20].

It is very important to evaluate the new antiviral chemicals. They need to be effective only on the virus metabolism, and stop virus replication, but have no effect on plant metabolism which is not easy indeed [3].

\section{Plant as a source of virucides}

The Ancient Egyptians and Chinese used plants for treating a lot of important health issues, and different diseases, also for preparing hundreds of medicinal products; this is shown in their records [21]. Eighty percent of the world's population use medicinal plants products for fighting different pathogens. Many records are published about medicinal plants used in folk medicine for their high level of effectiveness as antiviral agent. Some of them have been approved ability to treat viral infections in animals and people [22,23]. In 1925 Duggar and Armstrong found the first plant inhibitors, they discovered that TMV replication was inhabited by the extracts from different plants [24]. During the following 25 years, a lot of progress was achieved in the discovery of virus inhibitors $[25,26]$. The knowledge was very limited in the field of basic science in the 1950s when they started to search for antiviral agent, although luck interfered [27].

In Europe after the Second World War in 1952 the need for antiviral agents encouraged research in this field [28]. Boots drug company [Nottingham, England] screened less than three hundred different plants in search for an antiviral against influenza. These efforts were the first practical trial in the discovery of antiviral agents [29]. In 1964 a breakthrough occurred in this field. A plant survey was done and succeeded in characterizing antiviral substances as antibacterial, antifungal, and antiviral actions [30]. A great deal of knowledge became available about virus replication, accumulated through the previous thirty years which facilitated finding and recognizing more antiviral agents with high efficacy against virus diseases [31].

Antiviral agents must also be safe for the environment and field applications; therefore, scientists responsible for plant protection are very active and are always working hard trying to find antivirals with such characteristics [3].

\section{Mechanisms of antiviral activities}

Plant viruses depend on plant cell for replication [3]. The relationship between the virus replication and the host cell is very intimate; this is the first problem in the progress and thus needs a very effective antiviral. The second problem is the late identification of viral diseases when the treatment is not highly effective [32]. Antiviral's main target is viral nucleic acid, there are two kinds of viral nucleic acids which are Deoxyribonucleic Acid [DNA], and Ribonucleic Acid [RNA], containing the code responsible for viral replication in host cell and the spread of the virus and viral proteins, but there is not enough information about the stage of penetration at the virus propagation [33]. A good antiviral agent must stop the multiplication in the infected cell should not have any toxic effect on normal cells [32]. Antiviral chemical agents can stop the spread of the virus, control the visible symptoms and induce nature resistance by the host [3].

\section{Methods for investigating antiviral agent}

Screening and extraction for plants: It is amazing that antiviral products could be found in many different natural resources, for instance fungi, marine fauna and flora bacteria, and plants, however, the screening is usually focus on plants which are known to have medicinal background [34]. Screening for natural products can be explored by two methods the first by collecting plants randomly and the second by searching for plants that are common and known to have medicinal effects. In a study to evaluate both ways, it was found that, the second way resulted production of higher number of plants with active substances than the first way [35].

Mirabilis jalapa extracts from different parts of the plant [root, leaves and stem], induced inhibition of plant virus activity [36]. The root extracts of $B$. diffusa induced the highest antiviral activity when compared with the other $B$. diffusa parts extract and it was found to have antiviral effects on different hosts [37]. An extract of Potentilla arguta root, and the branch tip extract of Sambucus racemosa were used. Both were proven to have inhibitory effect [28]. Pokeweed [Phytolacca americana] contains 3 types of antiviral proteins PAP well defined as [PAP-I, PAP-II, and PAP-III] it is obtained from leaves but at different times and different season. Spring leaves, early summer leaves, and late summer leaves, sequentially [38].

Plants produce 2 types of natural metabolic products, where the first one is termed "primary metabolites" which is very important since it is very essential for plant growth and development, the second termed "secondary metabolites" it is extremely varied in structure, produced in an enormous variety and plays an important role in the relations between plants and their biotic and abiotic resistance [21]. Many antiviral natural substances have been obtained during the previous fifty years. Some have been used as a crude extract that may contain a number of non-active substances, while others have been used as purified or partially purified, thus the chemicals included are not identified, nor the mechanism of these compounds [20]. The kind of solvent that is used in plant extraction depends on the kind of the chemicals needed to be obtained, the purpose of use, the conditions of extraction and the storage medium [21].

Separation and identification of the compounds: Separation for plant extract materials is important, because the extracted sap has a mixture of different components and structures; usually Chromatography is used [21]. 
The determination of the detector depends on the structure of the component needed to be analyzed and the available analytical system. The same structure can be analyzed by more than one system [39]. The High Performance Liquid Chromatography System [HPLC] are almost available everywhere. UV or Diode Array Light [DAD] detectors quantify the analyzed component. Another common detector is Fluorescence [21]. In the last few years, extraction methods for phytochemedicinal products preparation and isolation, have significantly improved due to increased concern in traditional medicine [40]. There are numbers of Books and literature available in the market, for example to start with: Plant Drug Analysis: A Thin Layer Chromatography Atlas [41], and Laboratory Handbook for the Fractionation of Natural Extracts [42]. They all describe standardized extraction procedures for preparing antiviral component from medicinal plants [43].

The evaluation methods for antiviral agents: The evaluation for antiviral chemicals mostly has been done depending on two viruses which are TMV and PVX [44]. For field application, using the antiviral chemical substances as a spray on the foliar parts is the most common way in application, because this method is easy, simple and inexpensive equipments are not needed $[20,44]$. Granular method is convenient, promising, and most importantly it is safe on the environment, because the substance kept at the same spot of application [20]. Seed treatment is ignored and is not being used anymore as one of the application methods [45]. Substances used as antivirals need substantial methods for evaluation for testing the infected tissues several times after being treated [46]. Development of the local lesion assay makes evaluation and quantification for virus replication and inhibition easier and more reliable $[25,26]$. Local Lesion assay is used for viruses which have hosts reacting with the infection and this result in a local lesion. Local lesion method is a reliable assay to evaluate most of the compounds as an antiviral [20]. The number of local lesions is an indication of the effectiveness of the antiviral. A fewer number of local lesions means more antiviral effect [47]. The inhibition effect using antiviral proteins was evaluated in percentage using the following formula:

\section{Inhibition rate $=[C-T] \times 100 / C$}

$\mathrm{C}$ is the local lesion number mean in the plants used as a control, while $\mathrm{T}$ is the local lesion number mean in the treated plants [48]. Serological methods such as ELISA for example are available and faster [20]. Infected plants after using the tested antiviral substances were examined by ELISA double antibody sandwich [49], to estimate virus inhibition due to a correlation with the virus concentration, then Real time Polymerase Chain Reaction [PCR] was used for those plants that reacted negatively with ELISA test for more sensitive evaluation of the virus concentration [50].

\section{Resistance acquired by antiviral plants}

Natural resistance: Some plants have natural resistance and are able to defend themselves by preventing the virus from replication inside the plant cells [4]. Hundreds of cells are invaded by the virus after infection, but the infection is localized in the area of the leaf and does not spread to the other cells, hence it must be a kind of natural resistance that stops the virus replication [46].

Systemic resistance inducers: Some plants have virus inhibitors these are reported to prevent infection of viruses and to induce systemic resistance in non-treated parts of the plants [51-53]. For instance glycoproteins obtained from the root of Boerhaavia diffusa substance incites the antiviral system in the treated plants. The glycoprotein inhibits the infection of the virus by blocking virus replication $[51,52]$ and prompts the plant system to produce new proteins by activating the defense mechanism in susceptible hosts [54]. Host plants sprayed with Boerhaavia diffusa glycoprotein were found to have high antiviral activity in the sap extracted from the leaves [54-56], however in the sap extracted from the control plants [non treated], such activity was not detected. The explanation is that sap from treated leaves contains some antiviral agent [AVA] protein, which is not found in the control plants [55]. In a number of susceptible hosts $B$. diffusa glycoprotein was found to be successful in inciting high systemic resistance by stimulating the immunity system.

Whereas, the resistance induced by Clerodendrum aculeatum is systemic. Leaf extract from Clerodendrum aculeatum when applied as a spray it could prevent infection of some viruses transmitted by white fly and mechanically in a number of local lesion hosts and a systemic hosts $[57,58]$.

Ribosome-inactivating proteins [RIPs]: Several plants have the ability to be protected against virus infection, since they possess effective inhibiting substances, a few of them are purified and identified. These plants have ribosome inactivating proteins [RIPs] which are considered to be as defense related protein [59]. Pokeweed Antiviral Proteins [PAPs] from Phytolacca Americana [60], Mirabilis Antiviral Protein [MAP] from Mirabilis jalapa [61], and Carnation Antiviral Protein [dianthins] from Dianthus caryophullus [58]. Phytolacca is a genus that has several Ribosome-Inactivating Proteins [RIPs]. In 1925, PAP was discovered in the plant of pokeweed [24]. PAP has a very high ability to inhibit protein assembling, and can stop the transmission of a number of plant viruses [62]. PAP antiviral activity has several features which make it very powerful against all types of viruses and this ability as an antiviral is quite strong even at minimal concentrations.

Mirabilis jalapa extract from different parts of the plant [root, leaves, and stem], induces an inhibiting effect for the plant virus activity. The leaf extract of Mirabilis jalapa, when sprayed 24-hours before the virus inoculation, stops the symptoms of virus disease on a few systemic hosts. The infectivity test indicated that, $50-60 \%$ decrease in virus content was noticed in the treated plants. Mirabilis jalapa extract was able to control a number of viruses, which are spread by insects in systemic hosts. It was able to stop the increase of aphids and whiteflies population. The mechanical transmission of Turnip Mosaic Virus [TMV] and Potato Virus Y [PVY] were inhibited by Mirabilis Antiviral Protein [MAP] [36]. The sap extracted from carnation leaves induces inhibition of virus infection [63-65] Dianthus caryophyllus has two types of protein inhibitors, which are Dianthin 30 and, Dianthin 32 they are isolated from the leaves [66]. The proteins of carnation also induce systemic resistance [67].

Novel antiviral agents: Chemicals are considered very important, and should play a significant job with highly effectiveness and minimum side effects. Production of "intelligent" and environmentfriendly plant antiviral agents will give a significant protection for plants against viruses, crop yields will increase and the quality will improve without any side effects on users, customer needs, and the environment [3]. Ten years of research for making an innovation by discovering a novel green antiviral plant agents has led to successfully finding several new compounds with significant bioactivity as antivirus. Some novel structures with high plant antiviral bioactivity, such as $\alpha$ - aminophosphonate derivative Dufulin [Bingduxing], chiral cyanoacrylates, and GU188 were discovered. After successfully passing systemic R\&D work, a brand new compound was commercialized as an antiviral. It is able to prevent the losses caused by virus infection, it called Duflin. It is a new antiviral agent for plants. Duflin mode of action is activating the plant immune system, by decreasing the virus 
ability for infection and causing an aggregation to the virus particles. The need for green technology laid the way for developing safe and systemic new antiviral agent for plants [3].

Nanotechnology and nanoscience caused a boom in research and applications recently. Plant extracts or plant biomasses and microorganisms are being used in an eco-friendly way as biological organisms for production of nanoparticles, and as an alternative to chemical and physical methods [68]. A number of plant extracts or plant biomasses are used for extracellular biosynthesis of silver and gold nanoparticles, and they have been proved to be successful. Using plant extracts to synthesize metal nanoparticles is an important branch of biosynthesis of nanoparticles [69]. C. colocynthis which is widely grown in Egypt, Sudan and some African countries where it is used in folk medicine $[70,71]$ is also used. The aqueous extracts of this plant from its fruits, seeds, leaves and roots are being used to synthesize silver nanoparticles in a simple and not expensive method [69].

Natural sources are still in focus, and remain an important source for more substances which have an antiviral effect. It is vital to keep searching for antiviral agents that are valuable and with new structures [28]. Advances in plant virus elimination could be possible, by the new compound effective as an antiviral in human or animal medicine, keeping in mind that their effectiveness on plant viruses may be different [50].

\section{Conclusion}

Nature is still fertile and rich with an enormous number of different kinds of plants possessing an antiviral effect. They are highly variable; each regional area has its own special kind of plants which are not available elsewhere around the world. While screening for plant antivirals it's better to focus on plants known for their medicinal effect in folk medicine, to maximize the valuable results, saves time and effort. Also screening should expand on-to food crops, which has been proven not to have any toxic effect. Further studies need to be done on the plant extract to separate the different compounds determine the effective substances using standard methodology. Chemical virucide is not a magic solution for the plant virus diseases, but it's important and a vital link in the control system chain of the control system, it may even be expected to have the upper hand in the control system. Environment friendly measures and procedures should be kept in mind while working on the research and the production of chemical virucides. On the other hand, to increase the number of the plant antiviral agents used as a virucide for plants, we can apply the different plant antiviral agents that have been proven successful as antiviral compounds for human beings and animals, especially those which have a broad- spectrum antiviral activity. This is to save time and to guarantee that they successfully meet the food and drug regulations. At the moment nanotechnology is focused on the field of pharmaceuticals and medicine, but in the next decade it will be very important in the field of agriculture for the search and development of better, safer and more effective antimicrobial and antiviral agents.

\section{Acknowledgments}

This work was sponsored by grant-ship of the Scientific and Projects section [\#AD1401/01] at the Bibliotheca Alexandria. The author would like to thank Miss Enas Mostafa, Mr. Nader Zakhary volunteers at the Bibliotheca Alexandria for their efforts to write and edit this review.

\section{References}

1. Gergerich RC, Dolja VV (2006) Introduction to plant viruses, the invisible foe. The Plant Health Instructor, DOI: 10.1094/PHI-I-2006-0414-01.
2. Hadidi A, Khetarpal RK, Koganezawa H (1998) Plant virus disease control. The American Phytopathological Society, St. Paul, USA: APS press.

3. Song B (2010) Environment-friendly antiviral agents for plants. Philadelphia, USA: Springer Science + Business Media LLC

4. Wassenegger $M$, Pelissier $T$ (1998) A model for rna-mediated gene silencing in higher plants. Plant Molecular Biology 37 349-62.

5. Pico B, Diez MJ, Nuez F (1996) viral diseases causing the greatest economic losses to the tomato crop. li. The tomato yellow leaf curl virus - a review. ScientiaHorticulturae 67: 151-96.

6. Matthews R (2001) Plant virology. New York, USA: Academic Press.

7. Cassells AC (1983) Chemical control of virus diseases of plants. Prog Med Chem 20: 119-155.

8. Stace-Smith R (1990) Tissue culture in plant viruses. Boca Raton, USA: CRC Press.

9. Hansen AJ, Lane WD (1985) Elimination of apple chlorotic leaf spot virus from apple shoots cultures by ribavirin. Plant Disease 69: 134-135.

10. Toussaint A, Kummert J, Maroquin C, Lebrun A, Roggemans J (1993) Use of virazole $\mathrm{R}$ to eradicate odontoglossum ringspot virus from in vitro cultures of cymbidium sw. Plant Cell, Tissue and Organ Culture 32: 303-309.

11. Borissensko S, Schuster G, Schmygla W (1985) Obtaining a high percentage of explants with negative serological reactions against viruses by combining potato meristem culture with phytoviral chemotherapy. Phytopathology Z. 114 185-188.

12. Bittner H, Schenk G, Schuster G (1987) Chemotherapeutical elimination of potato virus $x$ from potato stem cuttings. Journal of Phytopathology 120: 90-92.

13. Kopp M, Rouster J, Fritig B, Darvill A, Albersheim P (1989) Host-Pathogen Interactions : XXXII. A Fungal Glucan Preparation Protects Nicotianae against Infection by Viruses. Plant Physiol 90: 208-216.

14. Tomlinson JA (1981) Chemotherapy of plant viruses and virus diseases. In Harris KM, Maramorosch M (eds.) Pathogens, vectors and plant diseases: Approaches to control. New York, USA: Academic Press.

15. White RF, Antoniw JF (1983) Direct control of diseases. Crop pro. 2,259-271.

16. Verma H, Baranwal V, Srivastava S (1998) Antiviral substances of plant origin In: Hadidi A, Khetarpal RK, Koganezawa H (eds.) Plant Virus Disease Control. 539 Minnesota, USA: APS press 154-162.

17. Dawson W, Boyd C (1987) Modifications of nucleic acid precursors that inhibit plant virus multiplication. Phytopathology 77 477-80.

18. Sidwell RW, Huffman JH, Khare GP, Allen LB, Witkowski JT, et al. (1972) Broad-spectrum antiviral activity of Virazole: 1-beta-D-ribofuranosyl-1,2,4triazole-3-carboxamide. Science 177: 705-706

19. Murphy JF, Zehnder GW, Schuster DJ, Sikora EJ, Polston JE, et al. (2000) Plant growth-promoting rhizobacterial mediated protection in tomato against tomato mottle virus. Plant Disease 84: 779-784.

20. Hansen AJ, Stace-Smith R (1989) Antiviral chemicals for plant disease control. Critical Reviews in Plant Sciences 8 45-88.

21. Osbourn AE, Lanzotti $V$ (2009) Plant-derived natural products: Synthesis function, and application. Philadelphia, USA: Springer Science + Business Media LLC.

22. Thyagarajan SP, Thiruneelakantan K, Subramanian S, Sundaravelu T (1982) In vitro inactivation of HBsAg by Eclipta alba Hassk and Phyllanthus niruri Linn. Indian J Med Res 76 Suppl: 124-130.

23. Venkateswaran PS, Millman I, Blumberg BS (1987) Effects of an extract from Phyllanthus niruri on hepatitis $B$ and woodchuck hepatitis viruses: in vitro and in vivo studies. Proc Natl Acad Sci U S A 84: 274-278.

24. Duggar BM, Armstrong JK (1925) The effect of treating the virus of tobacco mosaic with the juices of various plants. Ann Missouri Botan Garden 12: 259 366

25. Matthews RE (1954) Effects of some purine analogues on tobacco mosaic virus. J Gen Microbiol 10: 521-532.

26. Francki RI, Matthews RE (1962) Some effects of 2-thiouracil on the multiplication of turnip yello mosaic virus. Virology 17: $367-380$.

27. Kinchingto D, Kangro DH, Jeffries DJ (1995) Design and testing of antivira 
compounds. In: Desselberger U (eds.) Medical Virology: A practical approach, New York, USA: Oxford University Press, 147-71.

28. Jassim SA, Naji MA (2003) Novel antiviral agents: a medicinal plant perspective. J Appl Microbiol 95: 412-427.

29. Chantrill BH, Coulthard CE, Dickinson L, Inkley GW, Morris W, et al. (1952) The action of plant extracts on a bacteriophage of Pseudomonas pyocyanea and on influenza A virus. J Gen Microbiol 6: 74-84

30. Kucera LS, Herrmann EJ (1966) Antiviral agents. Annual report in medicinal Chemistry 1 129-35.

31. Abdel-Haq N, Chearskul P, Al-Tatari H, Asmar B (2006) New antiviral agents. Indian J Pediatr 73: 313-321.

32. Duggar BM, Armstrong JK (1925) The effect of treating the virus of tobacco mosaic with the juices of various plants. Annals of the Missouri Botanical Garden 12: 359-66

33. Abonyi D, Abonyi M, Esimone C, Ibezim E (2009) Plants as sources of antiviral agents. African Journal of Biotechnology 8: 3989-3994.

34. Cos P, Vanden B, Tde B, Vlietinck A (2003) Plant substances as antivira agents: An update (1997-2001). Current Organic Chemistry 7: 1163-1180.

35. Williams JE (2001) Review of antiviral and immunomodulating properties of plants of the Peruvian rainforest with a particular emphasis on Una de Gato and Sangre de Grado. Altern Med Rev 6: 567-579.

36. Verma H, Kumar V (1980) Prevention of plant virus diseases by mirabilis jalapa leaf extract. New Botanist 7: 87-91.

37. Verma $H$, Awasthi L (1979) Antiviral activity of Boerhaavia diffusa root extract and the physical properties of the virus inhibitor. Canadian Journal of Botany 57: 926-32.

38. Rajamohan F, Venkatachalam TK, Irvin JD, Uckun FM (1999) Pokeweed antiviral protein isoforms PAP-I, PAP-II, and PAP-III depurinate RNA of human immunodeficiency virus (HIV)-1. Biochem Biophys Res Commun 260: 453-458.

39. Lesney MS (2004) HPLC takes the head in identifying food phytochemicals. Today's Chemist at Work 2: 32-36.

40. Ong ES (2004) Extraction methods and chemical standardization of botanicals and herbal preparations. J Chromatogr B Analyt Technol Biomed Life Sci 812: 23-33.

41. Wagner H (1996) Plant drug analysis: A thin layer chromatography atlas. Philadelphia, USA: Springer Science \& Business Media.

42. Houghton $P$, Raman A (1998) A laboratory manual for the fractionation of natural extracts. London, UK: Chapman \& Hall. Hudson JB (1990) Antiviral compounds from plants. Boca Raton, USA: CRC Press.

43. Mukhtar M, Arshad M, Ahmad M, Pomerantz RJ, Wigdahl B, et al. (2008) Antiviral potentials of medicinal plants. Virus Res 131: 111-120.

44. Dawson W, Schlegel D (1976) The sequence of inhibition of tobacco mosaic virus synthesis by actinomycin d, 2-thiouracil, and cycloheximide in a synchronous infection. Phytopathology 66: 177-81.

45. Nyland G (1973) Tetracycline therapy of pear decline and x-disease in peach and cherry. In: IX International Symposium on Fruit Tree Virus Diseases. Kent, UK: ISHS Acta Horticulturae 44.

46. Gera A, Spiegel S, Loebenstein G (1986) Production, preparation, and assay of an antiviral substance from plant cells. Methods Enzymol 119: 729-734.

47. Pardee K, Ellis P, Bouthillier M, Towers GH, French C (2004) Plant virus inhibitors from marine algae. Canadian Journal of Botany 82: 304-309.

48. Yang J, Jin GH, Wang R, Luo ZP, Yin QS (2012) Spinaciaoleracea proteins with antiviral activity against tobacco mosaic virus. African Journal of Biotechnology 11: $6802-8$.

49. Clark MF, Adams AN (1977) Characteristics of the microplate method of enzyme-linked immunosorbent assay for the detection of plant viruses. J Gen Virol 34: 475-483.

50. Spak J, Holý A, Pavingerová D, Votruba I, Spaková V, et al. (2010) New in vitro method for evaluating antiviral activity of acyclic nucleoside phosphonates against plant viruses. Antiviral Res 88: 296-303.
51. Verma H, Awasthi L, Mukerjee K (1979) Prevention of virus infection and multiplication by extracts from medicinal plants. Journal of Phytopathology 96 71-76.

52. Verma H, Awasthi L, Mukerjee K (1979) Induction of systemic resistance by antiviral plant extracts in non-hypersensitive hosts. Zeitschrift fur Pflanzenkrankheiten und Pflanzenschutz 8: 735-746.

53. Verma H, Baranwal VK, Srivastava S (1998) Breeding for resistance to plant viruses. In: Hadidi A, Khetarpal RK, Koganezawa (eds.) Plant Virus Disease Control, APS Press, Paul, MN, USA, pp.154-162.

54. Verma $H$, Awasthi $L$ (1980) Occurrence of a highly antiviral agent in plants treated with Boerhaavia diffusa inhibitor. Canadian Journal of Botany 58: 21412144.

55. Verma HN, Mukerjee K, Awasthi LP (1980) Determination of molecular weight of a polypeptide inducing resistance against viruses. Naturwissenschaften 67 : 364-365.

56. Singh A (2006) Comparative studies on control of certain ailments of plants, mice and cancer cell lines and in vitro stimulation of growth of plants and virus resistance using phytoproteins from Boerhaaviadiffusa and Clerodendrumaculeatum. Lucknow, India: LucknowUniversit, PhD thesis.

57. Verma H, Chowdhury B, Rastogi P (1984) Antiviral activity in leaf extracts of Different Clerodendrum Species Zeitschrift fur pflanzenkantheiten und flanzenschutz 91: 34-41.

58. Verma H, Varsha N, Baranwal VK (1995) Endogenousvirus inhibitors from plants, their physical and biological properties. In: Chessin M, DeBorde D, Zip A (eds.) Antiviral proteins in higher plants. Boca Raton, USA: CRC Press.

59. Tumer NE, Hudak K, Di R, Coetzer C, Wang P, et al. (1999) Pokeweed antiviral protein and its applications. Curr Top Microbiol Immunol 240: 139-158.

60. Barbieri L, Aron GM, Irvin JD, Stirpe F (1982) Purification and partial characterization of another form of the antiviral protein from the seeds of Phytolacca americana L. (pokeweed). Biochem J 203: 55-59.

61. Kubo S, Ikeda T, Imaizumi S, Takanami Y, Mikami Y (1990) A potent plant virus inhibitor found in mirabilis jalapa I. Annals of the Phytopathological Society of Japan 56: 481-487.

62. Irvin JD (1995) Antiviral proteins from phytolacca. In: Chessin M, DeBorde D, Zipf A (eds.) Antiviral proteins in higher plants. Boca Raton, USA: CRC press 65-94.

63. Ragetli HW, Weintraub M (1962) Purification and characteristics of a virus inhibitor from Dianthus caryophyllus L. I. Purification and activity. Virology 18 232-240.

64. Ragetli HW, Weintraub M (1962) Purification and characteristics of a virus inhibitor from Dianthus caryophyllus L. II. Characterization and mode of action. Virology 18: 241-248.

65. Van kammen A, Noordam D, Thung TH (1961) The mechanism of inhibition of infection with tobacco mosaic virus by an inhibitor from carnation sap. Virology 14: 100-108.

66. Stirpe F, Williams DG, Onyon LJ, Legg RF, Stevens WA (1981) Dianthins ribosome-damaging proteins with anti-viral properties from Dianthus caryophyllus L. (carnation). Biochem J 195: 399-405.

67. Plobner L, Leiser R (1990) Induction of virus resistance by carnation proteins In: Proceedings of the international congress on virology, Berlin, Germany 21 26.

68. Surana R, Aher A, Pal S, Deore U (2011) Evaluation of anthelmintic activity of Ixora coccinea. International Journal of Pharmacy \& Life Sciences 2: 813-814.

69. Sadowski Z (2010) Biosynthesis and application of silver and gold nanoparticles In: Perez DP (ed.) Nanotechnology and Nanomaterials. Rijeka, Croatia: InTech $257-76$

70. Kumar S, Kumar D, Manjusha, Saroha K, Singh N, et al. (2008) Antioxidant and free radical scavenging potential of Citrullus colocynthis (L.) Schrad. methanolic fruit extract. Acta Pharm 58: 215-220.

71. Gurudeeban S, Ramanathan T (2010) Antidiabetic effect of citrulluscolocynthis in alloxon-induced diabetic rats. Inventi Rapid: Ethnopharmacology 1: 112-5. 